\title{
A Comparative Study of Intra-Seasonal Variability of Total Column Ozone Measured over the Tropical Maritime and Coastal Stations Using Microtop II Ozonometer
}

\author{
Vazhathottathil Madhu, Gangadharan Karthika \\ Department of Atmospheric Sciences, Cochin University of Science and Technology (CUSAT), Cochin, India \\ Email: madhuv68@gmail.com
}

How to cite this paper: Madhu, V. and Karthika, G. (2018) A Comparative Study of Intra-Seasonal Variability of Total Column Ozone Measured over the Tropical Maritime and Coastal Stations Using Microtop II Ozonometer. Journal of Environmental Protection, 9, 175-193.

https://doi.org/10.4236/jep.2018.93013

Received: January 16, 2018

Accepted: March 16, 2018

Published: March 19, 2018

Copyright $\odot 2018$ by authors and Scientific Research Publishing Inc. This work is licensed under the Creative Commons Attribution International License (CC BY 4.0). http://creativecommons.org/licenses/by/4.0/

\section{Open Access}

\begin{abstract}
The study of temporal and spatial distribution of ozone is very important for understanding the atmospheric chemistry and thereby its impact on environment, weather and climate. The intra-seasonal variability plays a major role in the inter-annual variability of weather parameters such as rainfall, temperature, pressure and atmospheric trace gas constituents such as atmospheric ozone. The strength of monsoon circulation and deep convection greatly modifies the atmospheric compositions and meteorological parameters such as rainfall amount, distributions of atmospheric trace gas concentrations and other weather parameters over the summer monsoon region. The daily total column ozone (TCO) measured over maritime station (Lakshadweep Island$10^{\circ} 10^{\prime} \mathrm{N} \& 73^{\circ} 30^{\prime} \mathrm{E}$ ) and coastal station (Cochin $-9^{\circ} 55^{\prime} \mathrm{N}$ and $76^{\circ} 16^{\prime} \mathrm{E}$ ) using Microtop II Ozonometer were considered for the comparative study of seasonal and intra-seasonal variability for the year 2015. The annual average of total column ozone over Lakshadweep Islands and Cochin was 290 DU and 280 DU respectively for the year 2015. The greater concentrations in daily TCO measurements over Lakshadweep Islands for all seasons compared to Cochin lead to the speculations that, the surface ozone concentration is more because of pollution from the diesel burning emissions, since the whole Island's population completely depends on diesel generator for the power supply. During winter season maritime station shows a decrease of $\sim 30 \mathrm{DU}$ in TCO over Lakshadweep Island compared to coastal station Cochin ( 18 DU) from the annual mean in the month of December. During pre-monsoon season TCO concentration is high over both locations. There is gradual increase of TCO concentration over Cochin from pre-monsoon to monsoon season and peak in the month of September, but decreasing TCO concentrations
\end{abstract}


measured over Lakshadweep during July to August. In the analysis it was found that Intra-Seasonal Variability (ISV) in total column ozone over Lakshadweep Islands and Cochin during summer monsoon season was modulated by the monsoon dynamics and convection, thereby changes in the photochemistry of ozone production and distributions over the monsoon region. Two significant intra-seasonal oscillations (ISOs) such as Madden Julian Oscillation (MJO) and Quasi-Biweekly Oscillations (QBW) were identified in the TCO during monsoon season. The MJO shows higher periodicity $(\sim 54$ days) over Lakshadweep Islands compared to the coastal station, Cochin ( 48 days). Intra-seasonal variability of TCO over the maritime and coastal stations varies with geographic locations, marine boundary layer characteristics and also with seasons. The intra-seasonal variability or ISOs controls the interannual variability of TCO over a region. Hence deeper knowledge of ISOs in trace gases such as ozone helps us to understand more about the regional climate and air quality.

\section{Keywords}

Total Column Ozone (TCO), Intra-Seasonal Variability, Air Pollution, Madden Julian Oscillation and South West Monsoon

\section{Introduction}

Distribution and variability of ozone are vital to the atmospheric thermal structure as it can exert great influence on regional and global climate. Ozone is a minor trace gas in the atmosphere, beneficial to human when it is in the stratosphere and harmful when it is in the troposphere. In the stratosphere, the region of the Earth's atmosphere from $\sim 10$ to 50 kilometers above the surface, where the chemical compound ozone ( $90 \%)$ plays a vital role in absorbing harmful ultraviolet radiations from the sun is called good ozone. During the past 20 years, concentrations of this important compound have been threatened by human-made gases released into the atmosphere, including those known as chlorofluorocarbons (CFCs). These chemical compounds as well as meteorological conditions in the stratosphere affect the concentration of stratospheric ozone. In suitable ambient meteorological condition (e.g., warm, sunny/clear day), UV radiation causes the precursors to interact photochemically in a set of reactions that result in the formation of ozone [1]. The regional variations of ozone mostly depend on temperature, which controls the chemical and dynamical processes related to the photochemical reactions in the atmosphere. Ozone forms in the stratosphere when there is free oxygen in the atmosphere in the presence of ultraviolet radiations from the sun. It forms the same way it is renewed when extreme UV radiation breaks oxygen molecules into two oxygen atoms (atomic oxygen), and the oxygen atoms collide into oxygen molecules and form ozone.

In the lower atmosphere from the surface (lower troposphere), the ozone 
$(\sim 10 \%)$ acts as air pollutant harmful to human and ecosystem health. It acts as a greenhouse gas in the lower atmosphere and affects earth-atmosphere radiative equilibrium which leads to extreme situations such as global warming and regional climate change. Tropospheric ozone is produced by photochemical oxidation of CO and volatile organic compounds (VOCs) in the presence of nitrogen oxides [2]. The recent rate of increase of tropospheric ozone, is due to the horizontal and vertical transport of ozone precursors from the regions of biomass burning and anthropogenic emissions [3]-[9], stratosphere-troposphere exchange (STE) processes [10] [11] [12] and lightening NOx in turn adversely affects the regional climate and air quality [13] [14]. The decreasing trend of stratospheric ozone leads to a stratospheric cooling and increasing trend of surface ozone warm; the troposphere leads to imbalances in the earth-atmospheric radiative systems.

From the chemical composition and transport perspective, monsoon convection coupled with the strong local emission sources of South and Southeast Asia produces a significant anthropogenic signature on the chemical composition at the upper troposphere and lower stratosphere [15] [16] [17] [18]. Deep convection associated with summer monsoon and long-range transport of ozone due to the monsoon circulation will modulate the column ozone distributions [8], [19]. These observations demonstrate that the summer monsoon provides a significant transport pathway for tracers between the upper troposphere and lower stratosphere (UTLS) region. The monsoon system is therefore relevant to scales and processes bridging regional air quality, climate change, and global chemistry-climate interaction.

Asian summer monsoon (ASM) is a dominant system in the boreal summer season [20]. The dynamical structure of the Asian summer monsoon upper troposphere and lower stratosphere is characterized by an anticyclonic flow pattern associated with the Tibetan High [21]. Satellite data shows that the anticyclone has a pronounced chemical signature with enhanced tropospheric sourced trace gas species. As a weather pattern, the Asian monsoon impacts the lives of more than a billion people. With rapid population and economic growth across the monsoon region, it becomes a pressing concern that the monsoon convection coupled to surface emissions is playing a significant role in the region's air quality. The uplift of pollutants also enhances aerosol-cloud interactions that may change the behaviour of the monsoon. The chemical transport effect of the monsoon system is seen from satellites as an effective transport path for pollutants to enter the stratosphere. Indian summer monsoon (ISM) and its onset ( $1^{\text {st }}$ June) over South Kerala coast (Cochin), associated with large-scale changes in dynamical parameters as well as local moisture parameters over the entire Indian subcontinent during the season [22].

The present analysis focused on the total column ozone variability during Indian summer Monsoon (ISM) season (part of ASM) based on daily total column ozone measurements using Microtop II Ozonometer for the year 2015. The study locations Lakshadweep Islands (Maritime station) and Cochin (Coastal 
station) are considered to be the most important region through which summer monsoon circulation enter the Indian subcontinent and progress towards the northern part of India with monsoon rainfall and changing atmospheric compositions during the season (June-September). This study is the first of its kind from these tropical locations to understand the sub seasonal variability of total column ozone during the summer monsoon season using daily in situ measurements of TCO with Microtop II Ozonometer. Total column ozone shows sub seasonal variability (intra-seasonal oscillations) with different time scales during the summer monsoon period. The important timescales of different intra-seasonal variations have been identified in the past three decades in various meteorological parameters and the atmospheric compositions as the $10-20$ and the 30 - 50 day scales, in addition to the synoptic scales [21], [23]-[28]. This analysis focused on the intra-seasonal variability (ISV) of total column ozone during the summer monsoon season, because the monsoon convection and dynamics alter the atmospheric compositions through the photochemistry and chemical transport.

\section{Instrument and Methods}

The Global Ozone Observing System $\left(\mathrm{GO}_{3} \mathrm{OS}\right)$ of the Global Atmosphere Watch (GAW) programme of the World Meteorological Organisation (WMO) employs various total ozone measuring instruments, among them the Dobson Spectrometer, originally developed in the 1920s, then modern, automated Brewer Spectrometer, available since the early 1980s have shown their reliability and accuracy in the long-term ground measurements of total column ozone. The disadvantage of the spectrometer is their high price, high cost of operation and maintenance and large size and weight, which is adverse for field campaigns. Well trained staff requires to achieve good results and to keep the instruments well calibrated over a long time of operation. These reasons have prevented popularity of the spectrometer for ozone measurements especially in developing countries, which cannot afford the high instrumental and personal expenses. The recent development of a small, inexpensive, hand-held filter Ozonometer such as the MICROTOPS by Solar Light Co. accelerated the total ozone measurements worldwide with less expense, accurate with WMO standard [29]. The Comparative study of TCO measurements using Microtop II Ozonometer with other ground-based spectrometer measurements and satellite observations are already available for the reference [30] [31]. The present paper is based only on the in-situ measurements of TCO using Microtop II Ozonometer and the comparison with satellite and reanalysis TCO were already discussed in the previous study [28].

\subsection{Microtop II Ozonometer}

The Microtop II Ozonometer is a portable five-channel sun-photometer for measuring total ozone column as per WMO standard easily, accurately and de- 
pendably with a full field of view of $2.5^{\circ}$ [29]. The Ozonometer features $2 \%$ accuracy, which is comparable to much larger and more expensive instruments. It is designed for use as a hand-held manually operated instrument. Many options are available to facilitate field operations, such as a separate GPS receiver for the field measurements. The Sun photometer measures solar radiance in five spectral wave bands from which it automatically derives total columnar ozone. The instrument has five optical collimators aligned to aim in the same direction. A narrow-band interference filter and photodiode suitable for the particular wavelength range are fitted with every channel. All the channels face directly the solar disc simultaneously, when the image of the sun is focused at the cross-hairs of the sun target. When the radiation capture by the collimators falls on to the photodiodes, it produces an electrical current proportional to the received radiant power, which is amplified and is converted into digital form in a high-resolution A/D converter. Signals are processed in a series of 20 conversions per second. It measures direct solar ultraviolet radiation at 3 discrete wavelengths within the UV range $(305,312,320 \mathrm{~nm})$ for the total column ozone, as well as total water vapor $(954 \mathrm{~nm})$ and aerosol optical thickness $(1020 \mathrm{~nm})$ respectively. This instrument gives a better accuracy and performance during the measurements. The physical and operational characteristics of the Microtop II Ozonometer instrument are detailed in the "User's Guide", which is publicly accessible on the Internet (https://solarlight.com/product/microtops-ii-ozonometer/).

\subsection{Data Acquisition and Analysis}

Total column ozone (TCO) variability over the maritime station (Lakshadweep Island) and costal station (Cochin) have been studied using the daily TCO measurements using Microtop II Ozonometer for the year 2015. The columnar ozone is measured in Dobson Unit (DU) and it represents the height of stack of ozone molecules at the surface of the Earth, collected from a column of air above the stack. This instrument works only on day time, since it is a sun targeted instrument calculate total column ozone using shortwave radiations from the sun in the UV wavelength range. To compute the daily average of TCO over these stations, two observations were taken, one in the morning and other in the late afternoon hours of every day in the year 2015. Monthly total column ozone is calculated for these stations by taking daily average of respective months (average of more than 20 daily observations of the respective month). To study the seasonal variations of TCO over these locations, monthly departure of TCO computed from the annual mean value of TCO over these stations. Since the instrument is sun targeted and not automated, measurement of column ozone is possible only during day time with discrete frequency of measurements with few days data gaps in every month. The cloudy days during monsoon period, restricted the daily measurements of total column ozone over these locations with few days (two or three days gap in certain months) data gap due to cloudy conditions and non-visibility of sun due to the monsoon clouds. These data gaps 
were filled with linear interpolation techniques to construct the continuous daily TCO for these stations to study the intra-seasonal variability of TCO associated with monsoon induced circulation. Daily anomaly of TCO for the monsoon season were calculated by subtracting the monsoonal seasonal mean of TCO (June to September) from the daily observations for the season.

In order to study low and high frequency oscillations (ISOs) in column ozone, during the monsoon season (June-September), Discreet Mayer's Wavelet (DMW) method were adopted to split high and low frequency oscillations in the total column ozone. The wavelet techniques make it possible to recover weak signals from the noise. Wavelets are mathematical functions that spilt data into different frequency components, and then study each component with a resolution matched to its scale. Wavelet Transform converts a signal into a series of wavelets, which provide a way for analyzing waveforms, bounded in both frequency and time domain. They have advantages over traditional Fourier methods in analyzing physical situations where the signal contains discontinuities and sharp spikes [32] [33]. Wavelet analysis has attracted attention for its ability to analyze rapidly changing transient signals. Any application using the Fourier transform can be formulated using wavelets to provide more accurately localized temporal and frequency information. Like Fourier analysis, wavelet analysis deals with expansion of functions in terms of a set of base functions. Unlike Fourier analysis, wavelet analysis expands functions not in term of trigonometric polynomials but in terms of wavelets, which are generated in the form of translations and dilations of a fixed function called the mother wavelet. The wavelets obtained in this way have special scaling properties. They are localized in time and frequency, permitting a closer connection between the functions being represented and their coefficients. Through this method of splitting of data into its frequency components greater numerical stability in construction and manipulations is ensured. For the wavelet analysis, continuous daily TCO values over these locations were used to split the low and high frequency variabilities in TCO during summer monsoon season 2015. Figure 1 shows the study locations and the photograph of Microtop II Ozonometer instruments used for TCO measurements.

\section{Results and Discussion}

\subsection{Daily Distribution of TCO over Lakshadweep Islands and Cochin}

The regional atmospheric ozone concentration depends on the geographical and meteorological conditions of the measurement locations. A brief knowledge of the meteorological characteristics of the study locations is very much essential to understand the TCO variability over a region. The TCO measurements over the Maritime location (Lakshadweep) and the Coastal location (Cochin) have been chosen for the study. Both locations are geographically and mereologically very important for the study of TCO variability associated with summer monsoon 


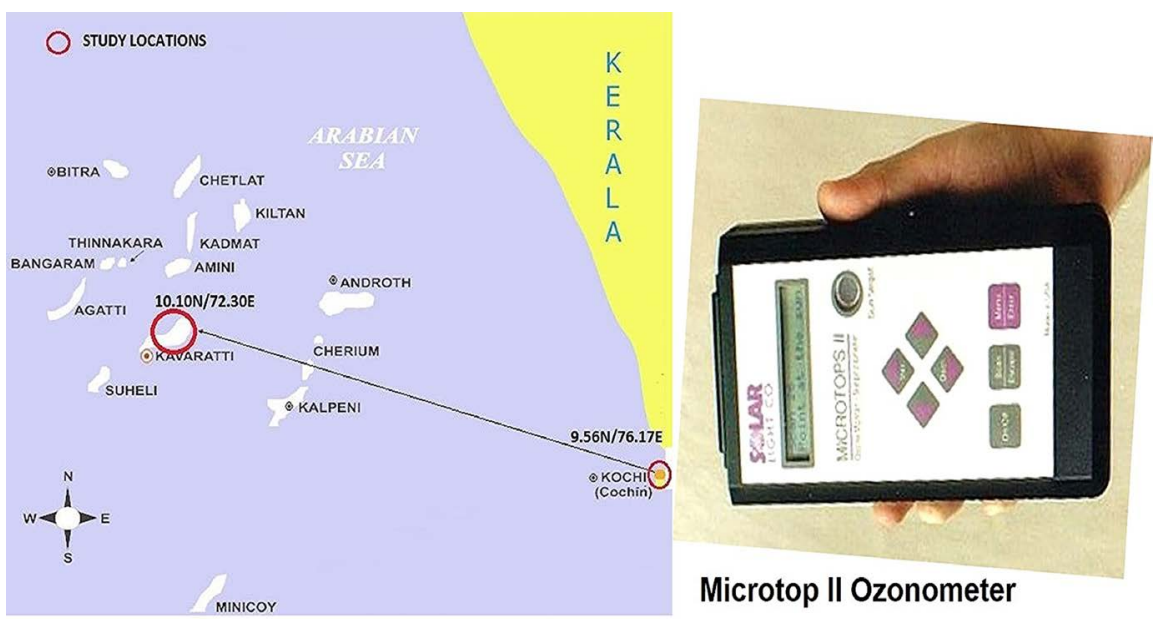

Figure 1. Study location map: Maritime stations (Lakshadweep Islands) and coastal stations (Cochin alias Kochi) the photograph of the instrument used for the total column ozone measurements (Microtop II Ozonometer).

(south-west monsoon) wind circulations and deep convection during the season. The open sea coral islands of Lakshadweep are one of the low lying small group of islands in the world. The low level of the islands of Lakshadweep makes them very sensitive to sea level rise and therefore the foremost future threat to these island chains is potential global climate change. The IPCC Report (2007) predicts a global sea level rise of at least $40 \mathrm{~cm}$ by 2100 that shall inundate vast areas on the coast, and up to 88 percent of the coral reefs, termed the "rainforests of the ocean", may be lost. Lakshadweep Islands is located approximately $300 \mathrm{~km}$ off the India's west coast (Cochin) into the Arabian Sea from the mean sea-level range 0.5 to $7.0 \mathrm{~m}$. However, there are only 36 islands having a total area of 32 sq. kilometers with a population 65,473 as per the 2011 census. The power is supplied in Lakshadweep Islands through diesel generating sets. The power generating systems in all the Islands are stand-alone systems. There is no inter island connection in the supply grid. About 66 lakhs litres of High Speed Diesel (a complex mixture of Hydro Carbons) oil is required annually for providing uninterrupted power supply in the Lakshadweep Islands. For this reason, the fuel burning emissions are very high over this region. The emissions from fuel oil combustion depend on the grade and composition of the fuel, the type and size of the boiler, the firing and loading practices used, and the level of equipment maintenance. Because the combustion characteristics of distillate and residual oils are different, their combustion can produce significantly different emissions such as particulate matter, sulphur dioxides ( $\mathrm{SOx}$ ), Nitrogen Oxides (NOx), Carbon Monoxide (CO), Volatile Organic Compounds (VOCs), and greenhouses gases $\left(\mathrm{CO}_{2}, \mathrm{CH}_{4}\right.$ and $\left.\mathrm{N}_{2} \mathrm{O}\right)$ during fuel oil combustion.

Lakshadweep has a tropical climate and it has an average temperature of $27^{\circ} \mathrm{C}$ - $32^{\circ} \mathrm{C}$. April and May are the hottest with an average temperature of $32^{\circ} \mathrm{C}$. Generally, the climate is humid warm and pleasant. The average rainfall received 
is $160.0 \mathrm{~cm}$ a year. Monsoon prevails here from $15^{\text {th }}$ May to $15^{\text {th }}$ September. The details of power generations in the Lakshadweep islands

(http://lakshadweep.nic.in/depts/electricity.htm) and Lakshadweep action plan on climate change (http://www.moef.nic.in/sites/default/files/sapcc/Lakshadweep.pdf) are publicly available on the internet. The fuel combustion emissions and Marine Boundary Layer (MBL) characteristic during the summer season can alter the concentration of ozone over Lakshadweep Islands.

Cochin alias Kochi, is a major port city on the south-west coast of India called as the Queen of Arabian Sea. Kochi is an important spice trading centre on the west coast of India from the $14^{\text {th }}$ century onwards and was the first of the European colonies in colonial India with present population of 2.1 million. The geographical location of Cochin $\left(9^{\circ} 58^{\prime} \mathrm{N}, 76^{\circ} 17 \mathrm{E}\right)$ is near to the equator and hence less seasonal variations in temperature and humidity. The annual average of maximum temperature is approximately $36.0^{\circ} \mathrm{C}$ and minimum around $16^{\circ} \mathrm{C}$ from the long term mean value. Cochin city is in the windward side of Western Ghats generally gets heavy rainfall during summer monsoon period (June to September) with an average annual rainfall $297.8 \mathrm{~cm}$ with average 125 rainy days in a year. This coastal city is also under the threat of seal level rise and climate change related extreme weather events. Cochin is a fast-developing city confronting with air pollution and related health problems due to increase emissions from transportations and new budding industries. These factors also enhance the surface ozone concentrations over the region in addition to the changes associated with summer monsoon dynamics and chemical transport during the season.

The Marine boundary layer $(\mathrm{MBL})$ is considered as a net sink of ozone $\left(\mathrm{O}_{3}\right)$ with photochemical destruction being the primary driving force [34] [35] [36] [37]. The hydroxyl radical produced by photochemical destruction of $\mathrm{O}_{3}$ and its subsequent interaction with water molecule are important mediators in either the production or destruction of ozone. The ability of the atmosphere to produce or destroy surface ozone is a non-linear function dependent on the availability of NOx and non-methane hydrocarbons. In low NOx conditions prevalent in the remote Marine Boundary line, destruction dominates [38]. Advection from the adjoining land mass is a major factor controlling the level of $\mathrm{O}_{3}$ in the marine boundary layer. Biomass burning over the nearby landmass can also lead to enhanced levels of $\mathrm{O}_{3}$ and its precursors in the marine atmosphere [39] [40] [41], [9]. Over the tropics, lightning activity is most intense and thus, the NOx produced is a major precursor for the production of ozone. Deep convection associated with summer monsoon and long-range transport of ozone due to the monsoon circulation will modulate the intra-seasonal variability of column ozone concentrations [8] [28] [42].

Figure 2 represent the daily variation of total column ozone over the maritime station (Lakshadweep Islands) and coastal station (Cochin) using the Microtop II Ozonometer measurements. Total column ozone varies $~ 250$ to $320 \mathrm{DU}$ 


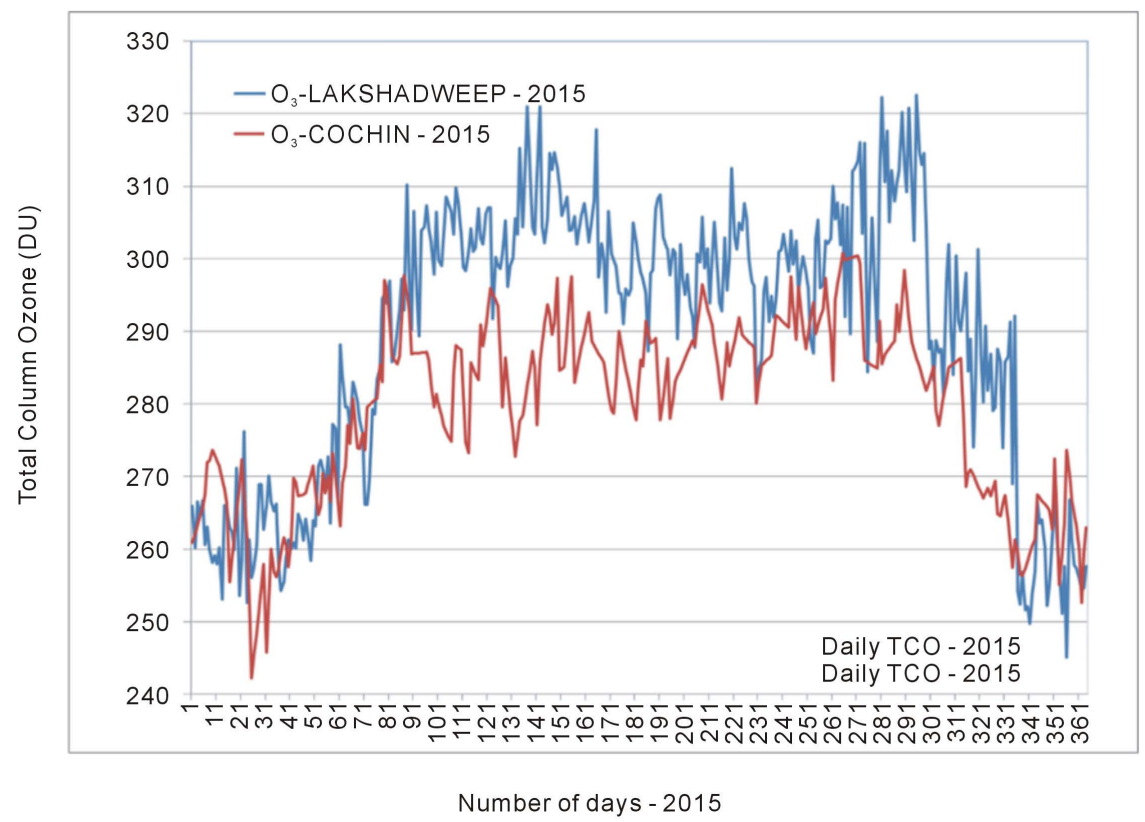

Figure 2. Daily variation of total column ozone measured over the Maritime location (Lakshadweep) and coastal location (Cochin) using Microtop II Ozonometer during 2015.

over Lakshadweep Islands with a difference of $\sim 70 \mathrm{DU}$ with maximum and minimum and for the coastal stations Cochin, TCO fluctuate in the range $\sim 245$ DU to $300 \mathrm{DU}$ with difference of $\sim 55 \mathrm{DU}$ with maximum and minimum during the year 2015. The concentration of surface ozone production due to the regional pollution sources such as NOx and other emissions are expected to be more in Lakshadweep Islands and it contributes more to the total column ozone concentrations compared to Cochin. Hence total column ozone concentration over Lakshadweep Islands depend on the seasonal marine boundary layer characteristics, surface ozone contributions due to the fuel burning emissions, apart from the latitudinal and seasonal dependence in TCO variability. The above factors are also affect TCO concentration over Cochin.

\subsection{Monthly TCO over Lakshadweep Islands and Cochin}

Previous studies reveal that surface ozone measurements over the marine environment of the Arabian seas during the pre-monsoon months are very high and the $\mathrm{O}_{3}$ mixing ratio showed a positive correlation with aerosol loading [35] [43]. Comparative study of TCO measurements using Microtop II Ozonometer and ECMWF reanalysis TCO revealed that TCO concentrations is higher during monsoon seasons [28]. Figure 3 shows the monthly departure of total column ozone from the annual mean value over Lakshadweep Islands and Cochin during 2015. During winter (December-January-February, DJF) both stations measured less TCO concentrations. For this season, a negative departure of $\sim 30$ DU over Lakshadweep Islands from the annual mean $(290 \mathrm{DU})$ and 18 DU over Cochin from the annual mean $(280 \mathrm{DU})$ recorded in the month of December. 


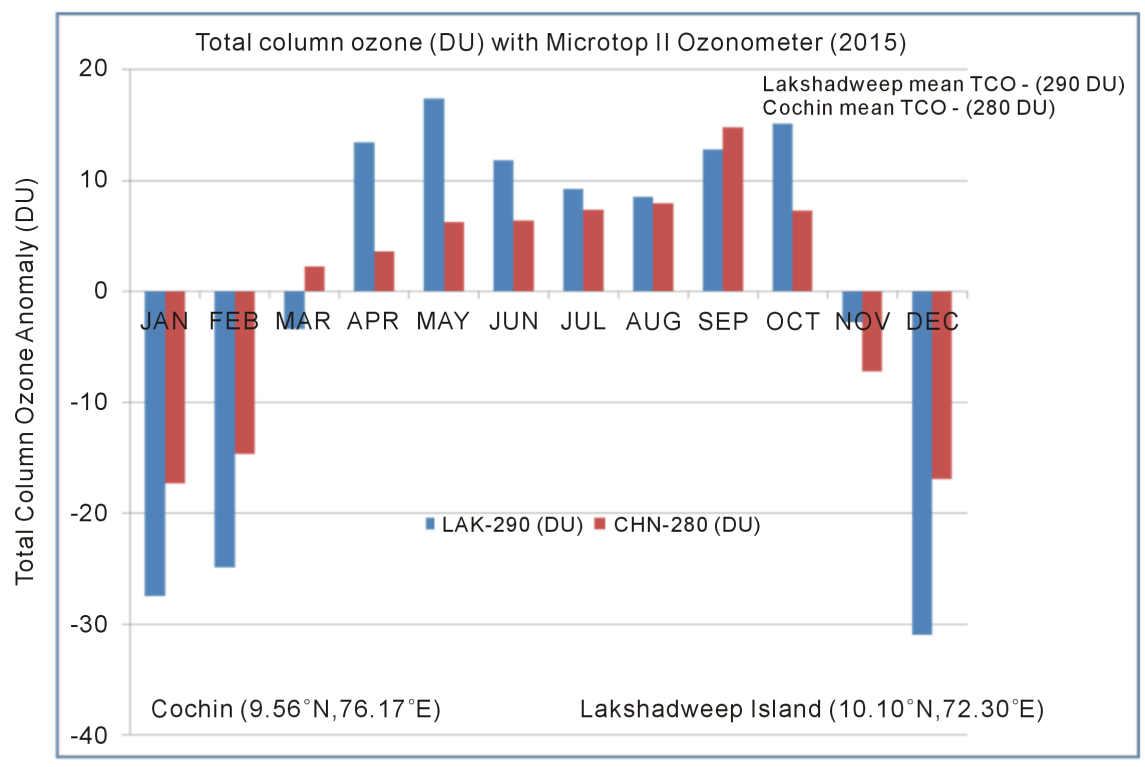

Months - 2015

Figure 3. Monthly departure of TCO (in DU) from the annual average of TCO for Lakshadweep Islands and Cochin for the year 2015.

During pre-monsoon season (March-April-May, MAM) to the month of October including the post monsoon season (October-November), TCO shows a positive departure from the annual mean for both stations. During pre-monsoon and post monsoon seasons TCO are very high over Lakshadweep Islands and gradual increase of TCO noticed over Cochin from pre-monsoon season to monsoon season with a peak value in the month of September (>20 DU from the annual mean) during the year 2015. Contrary to the TCO variability over Cochin during monsoon season, Lakshadweep Islands shows decreasing concentrations of TCO during summer monsoon months (June-July-August). Monthly lag of TCO concentrations were noticed between Lakshadweep Islands and Cochin stations during summer monsoon period (June to September), may be connected with the advancement of summer monsoon wind induced transport of ozone rich air from the southern latitudes through Lakshadweep islands to the coastal station Cochin. However, the seasonal mean of TCO over Lakshadweep (300 DU) is greater than the seasonal mean of Cochin (289 DU) during the summer monsoon 2015. A seasonal difference of more than $10 \mathrm{DU}$ noticed in the TCO between maritime stations (Lakshadweep Islands) and coastal station (Cochin) during 2015. This seasonal difference in TCO between maritime and coastal stations may be due to the monsoon boundary layer influence and the fuel combustion emissions over Lakshadweep Islands, may add more surface ozone to the total column ozone compared to the coastal station (Cochin). In order to study contribution of surface ozone to the total ozone over Lakshadweep Islands requires more ground-based surface ozone observations in conjunction with the emission records of fuel burning for the power generation in the Lakshadweep Islands. 


\subsection{Intra-Seasonal Variability of TCO during Summer Monsoon}

The upper troposphere-lower stratosphere (UTLS) of the Asian summer monsoon (ASM) region is characterized by a continental scale anticyclonic circulation, which is dynamically active and coupled to monsoonal convection. The monsoon anticyclone exhibits anomalous chemical and aerosol characteristics, linked to the outflow of deep convection and the large-scale circulation, and strongly influences the global UTLS composition during boreal summer [44]. It is poorly understood the dynamical and chemical coupling with convection, three-dimensional transport pathways from the surface to the stratosphere, composition/reactive chemistry in the monsoon region, as well as microphysics and the tropopause aerosol layer. Indian Summer Monsoon Rainfall (ISMR) shows strong variability on intra-seasonal timescale, in addition to decadal and interannual timescales [21], [45]. The dominant intra-seasonal modes found in ISMR are synoptic mode with 3 - 7 days period [46], quasi bi-weekly mode (qbw) with 10 - 20 days period [47], [24] [25] and Madden Julian Oscillation (MJO) with 30 - 40 days period [23] [24] [25].

The intra-seasonal oscillations (ISO) or intra seasonal variability (ISV) in the context of Indian Summer Monsoon period is generally a term used to describe the sub seasonal variability (viz., $\sim(20$ - 60) days periodicity) of various meteorological parameters related to the summer monsoon rainfall over India. The Madden-Julian Oscillation (MJO) is the largest element of the intra-seasonal (30 - 60 days) oscillations in the tropical atmosphere. It is a large-scale coupling between atmospheric circulation and tropical deep convection associated with summer monsoon, which changes the atmospheric compositions and its sub seasonal variability during June to September over the Peninsular India [19], [28] [48] [8]. The TCO variability on the seasonal timescale over India during monsoon season is governed by large-scale convective motion forced by diabetic heating [49]. Figure 4 shows the intra-seasonal variability of total column ozone (daily departure of TCO observations from the monsoon seasonal mean) over Lakshadweep Islands and coastal location for the year 2015. The monsoon seasonal mean of TCO over Lakshadweep and Cochin are 300 DU and 289 DU respectively for the year 2015. The total column ozone undergoes multi-time scale sub seasonal oscillations over these stations. The daily departure of TCO from the monsoonal mean over Lakshadweep and Cochin do not show exact phase correlation and a phase lag is noticed in the TCO variability during several days during the season.

Figure 4 clearly depicts, many small-time scales oscillations in TCO over Cochin and Lakshadweep Islands during the monsoon season. Previous studies of monsoon induced ozone variability over Indian subcontinent identified Madden Julian Oscillation and quasi bi-weekly oscillation in the total column ozone during monsoon season [27]. The amplitude of oscillations of TCO varies between $-10 \mathrm{DU}$ to $10 \mathrm{DU}$ during the season over Lakshadweep Islands and Cochin. Many significant sub seasonal time scale oscillations in TCO are not 


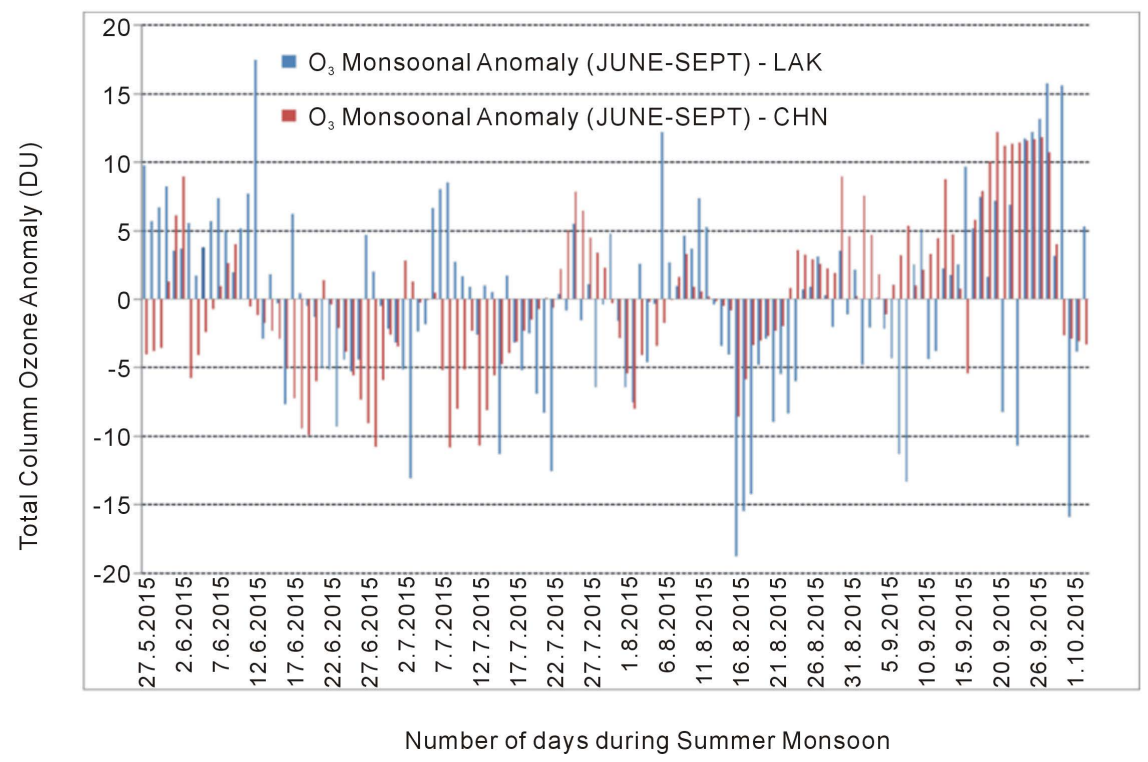

Figure 4. Daily total column ozone anomaly from the monsoon seasonal mean (27th May to 1st October) for Lakshadweep Islands and Cochin for the year 2015.

seen from the daily TCO departure and need to extract these significant oscillations though some other advanced statistical methods such as Fourier analysis or advanced time series analysis tool such as Wavelet techniques. To study the sub seasonal oscillations in the TCO, the wavelet analysis method is adopted to split the time domain TCO to the frequency domain TCO for better representations of the Intra-seasonal oscillations.

Figure 5 and Figure 6 represent the total column ozone observations and the corresponding intra-seasonal oscillations (sub seasonal variability) in TCO over Lakshadweep Islands and Cochin during the summer monsoon 2015. In Figure 5 \& Figure 6, the top panel represent total column ozone concentrations in Dobson unit in the $\mathrm{y}$-axis and number of days along the $\mathrm{x}$-axis during the monsoon season (June to September). The middle and bottom panels correspond to the intra-seasonal oscillation in TCO over Lakshadweep Islands and Cochin. In the middle and bottom panels, $y$-axis represent the wavelet coefficients (amplitude) of intra-seasonal oscillations in TCO (see Figure 5 \& Figure 6). There are two low frequency oscillations identified in TCO during monsoon seasons one with a periodicity ranging $\sim 30$ to 60 days, Madden Julian Oscillations (MJO) and the other with a periodicity ranging $\sim 7$ to 14 days (quasi -biweekly oscillation). The ISOs signals in TCO shows similar ISOs in the Indian Summer Monsoon Rainfall (ISMR), confirm the monsoon induced variability in TCO during the year 2015 [27] [46] [50]. The sub seasonal scale variabilities in the monsoon circulations and convective transport alter the concentration of atmospheric trace species over this region [48]. The sub seasonal oscillations such a MJO and quasi biweekly oscillations plays a greater role in the monsoon dynamics and associated variabilities in rainfall amount and changes in the atmospheric compositions over the monsoonal region. 

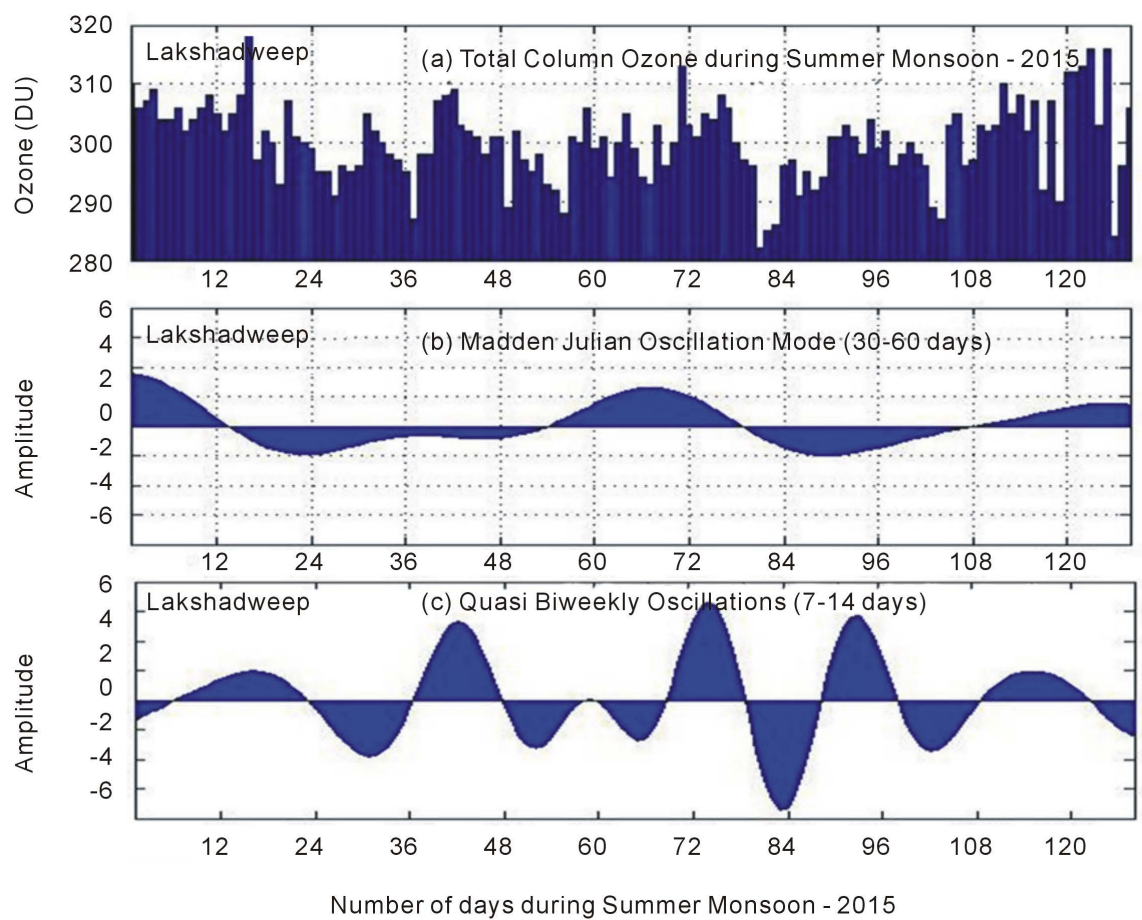

Figure 5. Total column ozone (in DU) over the maritime location (Lakshadweep Islands-top panel) and Wavelet coefficients (Amplitude of oscillations) to represent the intra-seasonal variability in the total column ozone (middle and bottom panel) during the monsoon season 2015 .
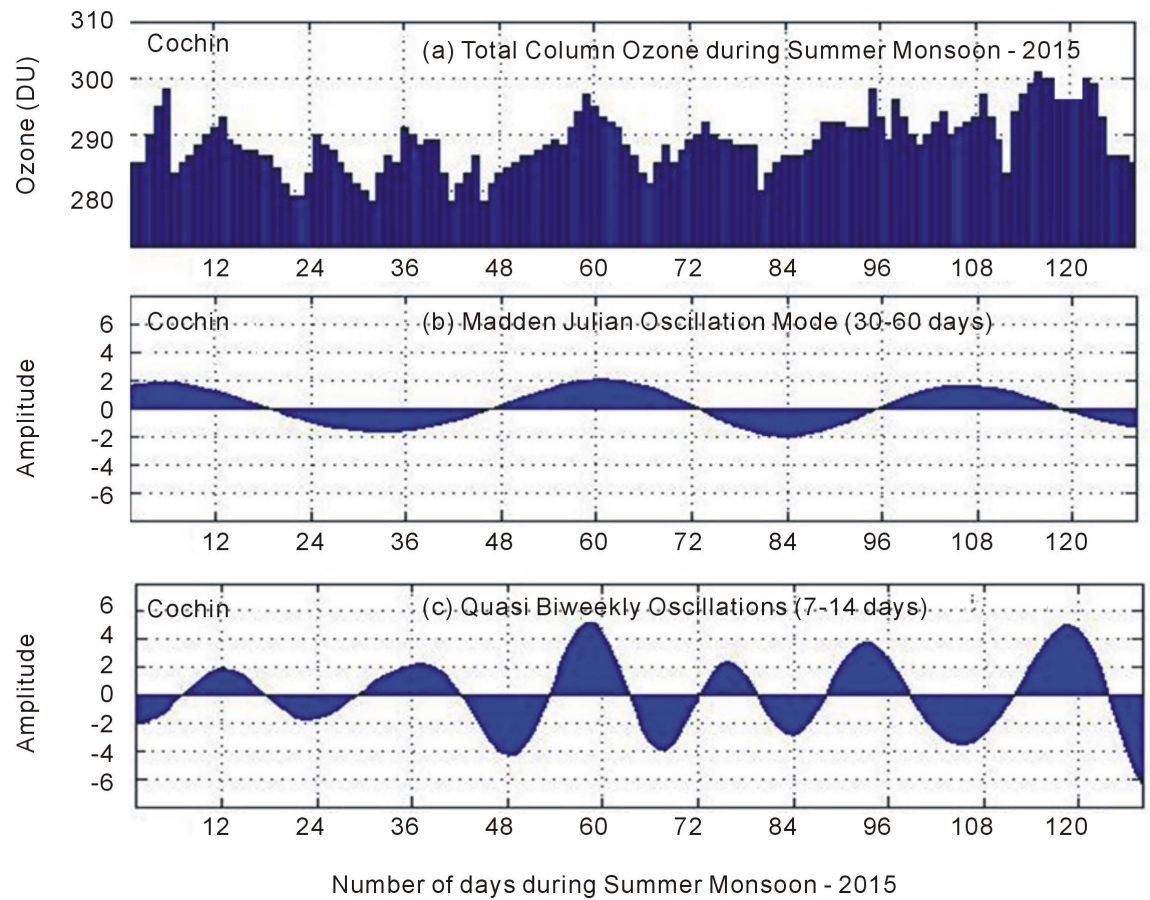

Figure 6. Total column ozone (in DU) over the maritime location (Cochin-top panel) and Wavelet coefficients (Amplitude of oscillations) to represent the intra-seasonal variability in the total column ozone (middle and bottom panel) during the monsoon season 2015. 
The amplitude and time period of Madden Julian Oscillations (MJO) and Quasi-Biweekly Oscillations (QBW) in TCO are different for maritime and coastal stations (see Figure $5 \&$ Figure 6). The dominant mode in the sub seasonal scale, MJO shows higher periodicity over the Lakshadweep Islands (MJO periodicity $\sim 54$ days) compared to the coastal stations Cochin (MJO $\sim 48$ days) during this season. The amplitude of ISOs represents the strength and significance of the sub seasonal variability in TCO. The quasi-biweekly oscillations show, clear sinusoidal signals with positive and negative phases, like the active and break cycles associated with the Indian summer monsoon rainfall [50]. The amplitude and period of ISOs are different for different years of summer monsoon, hence require several years of observations and modelling studies for the proper understanding of the intra-seasonal oscillations (ISOs) and associated changes in the atmospheric compositions (including the greenhouse gases and air pollutant such as surface ozone) during this season. The sub seasonal variability or ISOs are very crucial deciding factor for the interannual variability of total column ozone concentrations over a region.

\section{Conclusions}

The present study made a detailed analysis of TCO variability over the maritime location (Lakshadweep Islands) and coastal location (Cochin) using Microtop II Ozonometer measurements for the year 2015. The study reveals that TCO undergoes seasonal and sub-seasonal variability (ISOs) with different time scales such as MJO and quasi biweekly mode during the summer monsoon season. It is found that the MJO mode is having greater periodicity over the maritime location (periodicity $\sim 54$ days) compared to the coastal location ( $\sim 48$ days) during summer monsoon 2015. The annual mean TCO ( 300 DU) is also greater over Lakshadweep compared to Cochin ( 290 DU), which may be the greater contribution of surface ozone to the total column ozone, because of diesel burning emissions from the power generation and associated emissions (such as NOx and other air pollutants) over Lakshadweep Islands. More surface ozone measurement is required to understand the total column ozone variability over this region. There is a time lag in the ozone variability (TCO concentration) between Lakshadweep Islands and Cochin, which may be the influence of monsoonal wind circulations and associated transport of ozone rich air from the southern latitudes during the season. Maximum concentrations of TCO are noticed during pre-monsoon season over Lakshadweep and gradual increase of TCO is noticed over Cochin from pre-monsoon to monsoon season with a peak concentration in the month of September. The intra-seasonal oscillations (ISOs) in TCO are similar to the ISOs associated with Indian summer monsoon rainfall (ISMR), clearly indicating the monsoon induced variability in TCO. The marine boundary layer influence on TCO variability is more over Lakshadweep compared to Cochin.

To study the seasonal and sub-seasonal variability of TCO over Lakshadweep 
and Cochin, more factors such as marine boundary layer characteristics, monsoon dynamic and associated trace species transport should be considered. The increase of surface ozone and its contribution to the total column ozone due to anthropogenic emissions are also important in the estimation of TCO variability apart from its seasonal and latitudinal dependence. This is a preliminary observational study of total column ozone over these locations using one-year in situ measurements. Hence more observations of surface ozone and its contribution to the total column ozone from these locations and high resolution regional chemical transport models are essential to understand the monsoon induced intra-seasonal oscillations in total column ozone.

\section{Acknowledgements}

Author is indebted to Science and Engineering Research Board-Department of Science and Technology (SERB-DST), Government of India and the Department of Atmospheric Sciences, Cochin University of Science and Technology for the support to carry out this work successfully. Author is also thankful to the Director, Science and Technology and the Administrator of Lakshadweep Islands, India for granting permission for the Ozone measurements. Author is indebted to the research Staffs, Mr. Mohammed Shafi and Mr. Asif Sha T.M for the daily acquisition of total column ozone using Microtop II Ozonometer Instruments over the study locations. Author is also thankful to anonymous reviewers for their valuable comments and suggestions for the refinement of the manuscript for the present shape.

\section{References}

[1] Crutzen, P.J. (1971) Ozone Production Rates in an Oxygen-Hydrogen-Nitrogen Atmosphere. Journal of Geophysical Research, 76, 7311-7327. https://doi.org/10.1029/JC076i030p07311

[2] Logan, J.A., Prather, M.J., Wofsy, S.C. and McElroy, M.B. (1981) Tropospheric Chemistry-A Global Perspective. Journal of Geophysical Research-Oceans and Atmospheres, 86, 7210-7254. https://doi.org/10.1029/JC086iC08p07210

[3] Jacob, D.J., Heikes, B.G., Fan, S.M., Logan, J.A., Mauzerall, D.L., Bradshaw, J.D., Singh, H.B., Gregory, G.L., Talbot, R.W., Blake, D.R. and Sachse, G.W. (1996) Origin of Ozone and NOx in the Tropical Troposphere: A Photochemical Analysis of Aircraft Observations over the South Atlantic Basin. Journal of Geophysical Research Atmospheres, 101, 24235-24250. https://doi.org/10.1029/96JD00336

[4] Thompson, A.M., Pickering, K.E., McNamara, D.P., Schoeberl, M.R., Hudson, R.D., Kim, J.H., Browell, E.V., Kirchhoff, V. and Nganga, D. (1996) Where Did Tropospheric Ozone over Southern Africa and the Tropical Atlantic Come from in October 1992? Insights from TOMS, GTE TRACE A, and SAFARI 1992. Journal of Geophysical Research Atmospheres, 101, 24251-24278. https://doi.org/10.1029/96JD01463

[5] Jenkins, G.S. and Ryu, J.H. (2004a) Linking Horizontal and Vertical Transports of Biomass Fire Emissions to the Tropical Atlantic Ozone Paradox during the Northern Hemisphere Winter Season: Climatology. Atmospheric Chemistry and Physics, 4, 449-469. https://doi.org/10.5194/acp-4-449-2004 
[6] Jourdain, L., Worden, H.M., Worden, J.R., Bowman, K., Li, Q., Eldering, A., Kulawik, S.S., Osterman, G., Boersma, K.F., Fisher, B., Rinsland, C.P., Beer, R. and Gunson, M. (2007) Tropospheric Vertical Distribution of Tropical Atlantic Ozone Observed by TES during the Northern African Biomass Burning Season, Geophysical Research Letters, 34. https://doi.org/10.1029/2006GL028284

[7] Thouret, V., Saunois, M., Minga, A., Mariscal, A., Sauvage, B., Solete, A., Agbangla, D., Nedelec, P., Mari, C., Reeves, C.E. and Schlager, H. (2009) An Overview of Two Years of Ozone Radio Soundings over Cotonou as Part of AMMA. Atmospheric Chemistry and Physics, 9, 6157-6174. https://doi.org/10.5194/acp-9-6157-2009

[8] Chandra, N., Venkataramani, S., Lal, S., Sheel, V. and Pozzer, A. (2016) Effects of Convection and Long-Range Transport on the Distribution of Carbon Monoxide in the Troposphere over India, Atmospheric Pollution Research, 7, 775-785.

https://doi.org/10.1016/j.apr.2016.03.005

[9] Chandra, S., et al. (2009) Effects of the 2006 El Niño on Tropospheric Ozone and Carbon Monoxide: Implications for Dynamics and Biomass Burning. Atmospheric Chemistry and Physics, 9, 4239-4249. https://doi.org/10.5194/acp-9-4239-2009

[10] Sudo, K., Takahashi, M. and Akimoto, H. (2003) Future Changes in Stratosphere-Troposphere Exchange and Their Impacts on Future Tropospheric Ozone Simulations. Geophysical Research Letters, 30, 2256. https://doi.org/10.1029/2003GL018526

[11] Weller, R., Lilischkis, R., Schrems, O., Neuber, R. and Wessel, S. (1996) Vertical Ozone Distribution in the Marine Atmosphere over the Central Atlantic Ocean (56 Degrees S 50 Degrees N). Journal of Geophysical Research-Atmospheres, 101, 1387-1399. https://doi.org/10.1029/95JD02838

[12] Stohl, A., Bonasoni, P., Cristofanelli, P., Collins, W., Feichter, J., Frank, A., Forster, C., Gerasopoulos, E., Gaggeler, H., James, P., Kentarchos, T., Kromp-Kolb, H., Kruger, B., Land, C., Meloen, J., Papayannis, A., Priller, A., Seibert, P., Sprenger, M., Roelofs, G.J., Scheel, H.E., Schnabel, C., Siegmund, P., Tobler, L., Trickl, T., Wernli, H., Wirth, V., Zanis, P. and Zerefos, C. (2003) Stratosphere-Troposphere Exchange: A Review, and What We Have Learned from STACCATO, Journal of Geophysical Research-Atmospheres, 108, 748. https://doi.org/10.1029/2002JD002490

[13] Martin, R.V., Jacob, D.J., Logan, J.A., Bey, I., Yantosca, R.M., Staudt, A.C., Li, Q.B., Fiore, A.M., Duncan, B.N., Liu, H.Y., Ginoux, P. and Thouret, V. (2002) Interpretation of TOMS Observations of Tropical Tropospheric Ozone with a Global Model and In Situ Observations. Journal of Geophysical Research-Atmospheres, 107, ACH 4-1.

[14] Murray, L.T., Logan, J.A. and Jacob, D.J. (2013) Interannual Variability in Tropical Tropospheric Ozone and OH: The Role of Lightning. Journal of Geophysical Research-Atmospheres, 118, 11468-11480. https://doi.org/10.1002/jgrd.50857

[15] Randel, W.J. and Park, M. (2006) Deep Convective Influence on the Asian Summer Monsoon Anticyclone and Associated Tracer Variability Observed with Atmospheric Infrared Sounder (AIRS). Journal of Geophysical Research, 111, D12314. https://doi.org/10.1029/2005JD006490

[16] Randel, W.J., Park, M., Emmons, L., Kinnison, D., Bernath, P., Walker, K.A., Boone, C. and Pumphrey, H. (2010) Asian Monsoon Transport of Pollution to the Stratosphere. Science, 328, 611-613. https://doi.org/10.1126/science.1182274

[17] Vogel, B., Günther, G., Müller, R., Grooß, J.U. and Riese, M. (2015) Impact of Different Asian Source Regions on the Composition of the Asian Monsoon Anticyclone and on the Extratropical Lowermost Stratosphere. Atmospheric Chemistry 
and Physics Discussion, 15, 9941-9995. https://doi.org/10.5194/acpd-15-9941-2015

[18] Pan, L.L., Honomichl, S.B., Kinnison, D.E., Abalos, M., Randel, W.J., Bergman, J.W. and Bian, J. (2016) Transport of Chemical Tracers from the Boundary Layer to Stratosphere Associated with the Dynamics of the Asian Summer Monsoon. Journal of Geophysical Research: Atmospheres, 121, 14,159-14,174. https://doi.org/10.1002/2016JD025616

[19] Oman, L.D., Ziemke, J.R., Douglass, A.R., Waugh, D.W., Lang, C., Rodriguez, J.M. and Nielsen, J.E. (2011) The Response of Tropical Tropospheric Ozone to ENSO. Geophysical Research Letters, 38, L13706. https://doi.org/10.1029/2011GL047865

[20] Hoskins, B.J. and Rodwell, M.J. (1995) A Model of the Asian Summer Monsoon. Part I: The Global Scale. Journal of the Atmospheric Sciences, 52, 1329-1340. https://doi.org/10.1175/1520-0469(1995)052<1329:AMOTAS>2.0.CO;2

[21] Krishnamurti, T.N. and Bhalme, H.N. (1976) Oscillations of a Monsoon System. Part 1. Observational Aspects. Journal of the Atmospheric Sciences, 33, 1937-1954. https://doi.org/10.1175/1520-0469(1976)033<1937:OOAMSP >2.0.CO;2

[22] Ananthakrishnan, R. and Soman, M.K. (1988) The Onset of the Southwest Monsoon over Kerala: 1901-1980. International Journal of Climatology, 8, 283-296. https://doi.org/10.1002/joc.3370080305

[23] Krishnamurti, T.N. and Ardanuy, P. (1980) The 10 to 20 Day Westward Propagating Mode and "Breaks in the Monsoon". Tellus, 32, 15-26.

[24] Yasunari, T. (1980) A Quasi-Stationary Appearance of the 30-40 Day Period in the Cloudiness Fluctuations during the Summer Monsoon over India. Journal of the Meteorological Society of Japan, 58, 225-229.

[25] Yasunari, T. (1979) Cloudiness Fluctuations Associated with the Northern Hemisphere Summer Monsoon. Journal of the Meteorological Society of Japan, 57, 227-242. https://doi.org/10.2151/jmsj1965.57.3_227

[26] Lau, K.M. and Chan, P.H. (1986) Aspects of the 40-50 Day Oscillation during the Northern Summer as Inferred from Ongoing Long Wave Radiation. Monthly Weather Review, 114, 1354-1367. https://doi.org/10.1175/1520-0493(1986)114<1354:AOTDOD>2.0.CO;2

[27] Londhe, A.L., Padma Kumari, B., Kulkarni, J.R. and Jadhav, D.B. (2005) Monsoon Circulation Induced Variability in Total Column Ozone over India. Current Science, 89, 164-167.

[28] Madhu, V. and Gangadharan, K. (2016) Temporal Distribution of Total Column Ozone over Cochin-A Study Based on in Situ Measurements and ECMWF Reanalysis. Open Journal of Marine Science, 6, 200-209.

https://doi.org/10.4236/ojms.2016.62016https://doi.org/10.1029/2001JD900103

[29] Morys, M., et al. (2001) Design, Calibration, and Performance of MICROTOPS II Handheld Ozone Monitor and Sun Photometer. Journal of Geophysical Research, 106, 14,573-14,582. https://doi.org/10.1029/2001JD900103

[30] Kohler, U. (1999) A Comparison of the New Filter Ozonometer MICROTOP II with Dobson and Brewer Spectrometers at Hohenpeissenberg. Geophysical Research Letters, 26, 1385-1388. https://doi.org/10.1029/1999GL900245

[31] Kalita, G., Bhuyan, P.K. and Bhuyan, K. (2010) Variation of Total Columnar Ozone Characteristics over Dibrugarh, India and Comparison with Satellite Observations over the Indian Subcontinent. Indian Journal of Physics, 84, 635-639. https://doi.org/10.1007/s12648-010-0063-6

[32] Meyer, Y. (1993) Wavelets: Algorithms and Applications. SIAM, Philadelphia. 
[33] Mallat, S. (1997) A Wavelet Tour of Signal Processing. Academic Press, Cambridge.

[34] Johnson, J.E., Gammon, R.H., Larsen, J., Bates, T.S., Oltmans, S.J. and Farmer, J.C. (1990) Ozone in the Marine Boundary Layer over the Pacific and Indian Oceans: latitudinal Gradients and Diurnal Cycles. Journal of Geophysical Research, 95, 11,847-11,856. https://doi.org/10.1029/JD095iD08p11847

[35] Lal, S., Naja, M. and Jayaraman, A. (1998) Ozone in the Marine Boundary Layer over the Tropical Indian Ocean. Journal of Geophysical Research, 103, 18,907-18,917. https://doi.org/10.1029/98JD01566

[36] Lal, S. and Lawrence, M.G. (2001) Elevated Mixing Ratios of Surface Ozone over the Arabian Sea. Geophysical Research Letters, 28, 1487-1490. https://doi.org/10.1029/2000GL011828

[37] Thompson, A.M., Johnson, J.E., Torres, A.L., Bates, T.S., Kelly, K.C., Atlas, E., Greenberg, J.P., Donahue, N.M., Yvon, S.A., Saltzman, E.S., Heikes, B.G., Mosher, B.W., Shashkov, A.A. and Yegorov, V.I. (1993) Ozone Observations and a Model of Marine Boundary Layer Photochemistry during SAGA 3. Journal of Geophysical Research, 98, 16,955-16,968. https://doi.org/10.1029/93JD00258

[38] Ayers, G.P., Penkett, S.A., Gillett, R.W., Bandy, B.J., Galbally, I.E., Meyer, C.P., Elsworth, C.M., Bentley, S.T. and Forgan, B.W. (1996) Annual Cycle of Peroxides and Ozone in Marine Air at Cape Grim, Tasmania. Journal of Atmospheric Chemistry, 23, 221-252. https://doi.org/10.1007/BF00055155

[39] William, B.G. (2000) A Case Study of Transport of Tropical Marine Boundary Layer and Lower Tropospheric Air Masses to the Northern Midlatitude Upper Troposphere. Journal of Geophysical Research, 105, 3757-3769.

https://doi.org/10.1029/1999JD901022

[40] Fenn, M.A., et al. (1999) Ozone and Aerosol Distributions and Air Mass Characteristics over the South Pacific during the Burning Season. Journal of Geophysical Research, 104, 16,197-16,212. https://doi.org/10.1029/1999JD900065

[41] Gregory, G.L., Anderson, B.E. and Browell, E.V. (1996) Influence of Lower Tropospheric Ozone on Total Column Ozone as Observed over the Pacific Ocean during the 1991 PEM-West a Expedition. Journal of Geophysical Research, 101, 1919-1930. https://doi.org/10.1029/94JD02945

[42] Ziemke, J.R. and Chandra, S. (2003) A Madden-Julian Oscillation in Tropospheric Ozone. Geophysical Research Letters, 30, 2182. https://doi.org/10.1029/2003GL018523

[43] Nair, P.R., Liji, M.D., Aryasree, S.K. and Susan George, K.S. (2013) Distribution of Ozone in the Marine Boundary Layer of Arabian Sea Prior to Monsoon: Prevailing Airmass and Effect of Aerosols. Atmospheric Environment, 74, 18-28. https://doi.org/10.1016/j.atmosenv.2013.02.049

[44] Yu, P., et al. (2017) Efficient Transport of Tropospheric Aerosol into the Stratosphere via the Asian Summer Monsoon Anticyclone. Proceedings of the National Academy of Sciences, 114, 6972-6977. https://doi.org/10.1073/pnas.1701170114

[45] Chowdhury, A., Mukhopadhyay, R.K. and Sinha, R. (1988) Low Frequency Oscillations in Summer Monsoon Rainfall over India. Mausam, 39, 375-382.

[46] Gadgil, S. and Asha, G. (1992) Intra-Seasonal Variation of the Summer Monsoon I: Observational Aspects. Journal of the Meteorological Society of Japan, 70, 517-527. https://doi.org/10.2151/jmsj1965.70.1B_517

[47] Murakami, M. (1976) Analysis of Summer Monsoon Fluctuations over India. Journal of the Meteorological Society of Japan, 54, 15-31. 
https://doi.org/10.2151/jmsj1965.54.1_15

[48] Ravi Kumar, K., Valsala, V., Tiwari, Y.K., Revadekar, J.V., Pillai, P., Chakraborty, S. and Murtugudde, R. (2016) Intra-Seasonal Variability of Atmospheric $\mathrm{CO}_{2}$ Concentrations over India during Summer Monsoons. Atmospheric Environment, 142, 229-237. https://doi.org/10.1016/j.atmosenv.2016.07.023

[49] Hingane, L.S. (1990) Ozone Valley in the Subtropics. Journal of the Atmospheric Sciences, 47, 1814-1817. https://doi.org/10.1175/1520-0469(1990)047<1814:OVITS>2.0.CO;2

[50] Madhu, V. (2016) Madden Julian Oscillations in Total Column Ozone, Air Temperature and Surface Pressure Measured over Cochin during Summer Monsoon 2015. Open Journal of Marine Science, 6, 270-282.

https://doi.org/10.4236/ojms.2016.62022 